\title{
Article
}

\section{Popular tales of Pastors, Luxury, Frauds and Corruption}

Pentecostalism, Conspicuous Consumption, and the Moral Economy of Corruption in Nigeria

\section{Davide Casciano}

\author{
University of Bologna
}

\begin{abstract}
Access to consumption, especially to objects that are challenging to obtain, is one of the features contributing to the successful spread of Pentecostalism in West Africa. Pentecostal pastors have become central public figures, 'consumer stars,' whose display of wealth and luxury is key to their social legitimacy as preachers of the Prosperity Gospel. Moreover, their extensive and flexible social networks allow them and other bornagain Christians to be part of patronage networks internally perceived as moral. However, while their conspicuous consumption has inspired ecstatic supporters, it has also attracted criticism and accusations of fakery and corruption. This article aims to explore the relationships between consumption, especially conspicuous consumption, and discourses about the corruption of Pentecostalism in Nigeria. Accusations against Pentecostal pastors and their fraud schemes or corrupt practices seem to identify the moral limits between what is considered a righteous and an immoral consumption, describing the potential perils of purely individualistic hyper-consumerism. These popular tales of 'fake pastors', willing to do anything to enjoy a luxury life, allow us to understand how the born-again public is scrutinizing the opaque neoliberal entanglements between consumerism and corruption that characterize emerging elite's actions in Nigeria and elsewhere.
\end{abstract}

\section{Keywords}

Nigeria, Pentecostalism, consumption, corruption, fraud, moral economy

'God is stylish! Yes! He took time to embellish the world in the time of creation, He owns everything including the Gold, so why would there be a non-concurrence from his children in that regard? After all Jesus was well dressed. They wouldn't have demanded for his apparel if he they were grungy.' 
The above quotation is from a website description of an event sponsored by the Salvation Ministries, a Pentecostal church founded in Nigeria by pastor David Oyedepo in 1993. The service is devoted to the world of fashion, and Oyedepo himself, with his elegant white suites, seems to know a thing or two about style, but he is not alone. Biodun Fatoyinbo is the pastor and founder of the Common Wealth of Zion Assembly. This Pentecostal church started in 1999 in Ilorin, Nigeria, and is now present in Abuja, Lagos, Ilorin, Port Harcourt, and outside Nigeria, in the wealthy Dubai. Fatoyinbo became famous in Nigeria for his extravagant taste and style, which earned him the nickname 'The Gucci Pastor.' His love for luxury has never been a secret; and he has openly displayed it on several occasions, such as in a selfie posted online in 2016 in which he was carrying a Gucci Web Animalia GG Supreme Tote bag, which sold for $\$ 2,490$ at the time. In Nigeria, such displays of wealth are quite common among pastors of Pentecostal Christian churches. In West Africa, the phenomenon of access to consumption, which seems to recall in many ways 'conspicuous consumption' (Veblen 1899), has strongly contributed to the extreme success of Pentecostalism. However, it is also one of its most ambiguous elements. Outside and within the Pentecostal movement, accusations of fraud and corruption against Pentecostal pastors and their high lifestyle have steadily increased over time. At the same time, Pentecostal pastors have often acted as vehement critics of the country's leadership, accusing them of keeping the population in poverty.

Previous studies on corruption within African Pentecostal churches have focused on internal dynamics of reciprocity, patronage, and media aspects (Lauterbach 2019; Pype 2010; Smith 2021). Corrupt practices and fakery were mostly analyzed in relation to the wealth the Prosperity Gospel promoted in countries where inequalities still prevail (Smith 2001). Instead, the purpose of this paper is to examine a different aspect of Pentecostalism in Africa that is strongly correlated to popular allegations of corruption: consumption, and especially conspicuous consumption. Consumerism's central role for both Christian thought and within neo-liberal political economies has already been recognized (Meyer 2007). Despite this, little has been written on the relevance of conspicuous consumption in African Pentecostalism. Most of the widespread accusations of corruption and fraud against Pentecostal pastors are linked to their worldly and extravagant consumerist practices. However, pastors have become such an essential part of the Nigerian social landscape that their lifestyles, including their public display of (conspicuous) consumption, have become a model for many aspiring to a better position in society. Thus, by listening to popular allegations of corruption, it is possible to understand which forms of conspicuous consumption are still morally acceptable outside and within the born-again Christian community in Nigeria and what their limits are. Even when expressed in religious terms, these discourses suggest the dangers of a growing 'desocialization of consumption' (Lipovetsky 1987). These risks include the possibility of shifting away from any possible collective morality in consumption towards more rapacious, immoral, and individualistic behaviors. When they appear to be driven only by the desire to 
consume at all costs, many born-again Christians refer to Pentecostal leaders as 'fake' or 'corrupt'.

Following an introduction to the structural context and the historical roots of Pentecostalism in Africa, we will explore the importance of consumption in Pentecostal practices through two classic scholars, Max Weber (1920) and Thorstein Veblen (1899). Each of them wrote referring to different historical and geographical contexts in their studies. However, their analyses serve as a starting point for exploring the peculiar entanglement between consumption and Pentecostalism in Nigeria today. Then, we will examine the multiple roles that Pentecostal pastors play today in postcolonial Africa. Like other elites both in Africa and worldwide, leaders of the Pentecostal movement are able to act among different sectors of society. Therefore, they can influence the public and the private scene directly and indirectly by holding political positions and managing numerous private entities. According to several scholars, the emergence of an internal patronage network facilitates the rise of a 'moral economy of corruption' even within churches (Haynes 2012; Smith 2021). Yet, it is only by analyzing the multifaceted nature of these networks and the multiple roles of their actors that the characteristics of contemporary corruption, which extend far beyond the misuse of public funds, can be understood (Wedel 2012). These complex networks are also relevant because many accusations of corruption against Pentecostal leaders in Nigeria are related to the difficulty of assessing their extent. Therefore, local anxieties have been expressed in popular discourses concerning fake and corrupt pastors involved in the world of the 'occult economies' (Comaroff and Comaroff 1999), which refer to a mix of spiritual and material strategies to extract capital from the population (such as 'ritual killings'). These widespread accusations also engage with the origin and the end of consumer goods, illustrating the differences between a morally legitimized Pentecostal conspicuous consumption or commercial enterprise and a selfish, wicked, and occult desire to consume and reach power. Therefore, despite the promises of prosperity made by Pentecostalism and the role that conspicuous consumption plays in framing the various emerging elites in Nigeria, these performances open the doors to accusation of fakery and corruption. By looking at the conspicuous consumption of Pentecostal leaders, it is possible to understand what it means to be corrupt as a Pentecostal leader for both the public and the born-again community in Nigeria.

Part of this article derives from ethnographic observations and interviews conducted in Rome with diaspora members of a Nigerian Pentecostal church, the Redeemed Christian Church of God, in 2021. However, the following reflections also derive from my research experiences in Nigeria since 2011, focused on Pentecostal Christian churches, where themes of consumption and corruption have repeatedly come up. In many Pentecostal Churches in West Africa, the quest for wealth and its perils have intrigued a number of scholars (Meyer 2004; Robbins 2004), and conspicuous consumption has played a central role in the formation of emerging elites, well over Nigeria (Daloz 2002). Therefore, the issues discussed here are now being debated within Nigerian society as a whole instead 
of being confined to one denomination. Moreover, born-again Christians also make representations of corruption based on the media, the internet, and information from outside their religious communities. Thus, in addition to the actual practices or experiences of fraud and corruption within Nigerian Pentecostal churches, this paper will also analyze the broader discourses of corruption (Torsello 2021), the representations that the scrutinizing public, bornagain or not, reproduces when discussing fake and corrupt pastor figures.

\section{Pentecostalism and consumerism in Nigeria}

There are numerous approaches to the origins of the Pentecostal movement and as a result, there are 'narrower' and 'broader' definitions of it (Cartledge 2008). Definitions that focus more on the phenomenological aspects of Pentecostal religious experiences tend to pay less attention to historical divergences. However, they may accommodate a variety of places and protagonists at the outset of the movement, held together by certain experiential elements. Among these elements, there are the gifts to prophesy, heal, speak in tongues, and exorcise (Anderson 2013). The act of speaking in tongues confirms an individual's successful conversion to Pentecostalism through the baptism of the Holy Spirit. The radical nature of this conversion is further emphasized by the way converts are known, inspired by John 3:3, as ‘born-again’ Christians.

The first Pentecostal movement reached places as far as Nigeria through British and American missionaries and their magazines already during the 1920s. Later on, local splits gave rise to Pentecostal churches run entirely in Nigeria (Mohr 2013; Hackett 2012). Many locally founded Christian churches, founded before Pentecostalism, later became Pentecostal in their structures and practices (Ukah 2011). The first wave of Pentecostalism in Nigeria was one characterized by a rigid moral emphasis, which among other things, stressed modesty in life and in consumerism. During this period, the Pentecostal 'holiness movement' (as it was called) was mostly limited to university campuses in Nigeria (Ojo 2006). It was in the 1980s that Pentecostalism in West Africa reached its height, with the spread of a new doctrine: the Prosperity Gospel.

According to the Pentecostal Prosperity Gospel, God desires that Christians live prosperously. This novel approach to material wealth was a departure from the ascetic path of the first holiness movement. A large part of the origin of the Prosperity Gospel can be traced to specific Bible passages (such as Deuteronomy 28) and the influence of another U.S. movement, the 'World of Faith.' The Book of Genesis mentions the creative word of God, and certain preachers, such as E. W. Kenyon, argued that prayers have the power to influence reality, including material well-being. Oral Roberts, an American Pentecostal televangelist, focused primarily on controlling wealth, spreading his message via radio and television, and eventually founding a university. In the late 1970s, several young Africans, including Nigerians, began travelling and attending biblical schools such as the one run by Oral Roberts. 
Benson Idahosa, in 1971, was the first African and Nigerian student at the Dallas Bible School. His student David Oyedepo extended the Prosperity Gospel in Nigeria even more successfully during the 1980s. Therefore, the Pentecostal movement in Nigeria has acquired a transnational character, particularly between the 1960s and 1980s, while still developing distinctive characteristics and practices (Hackett 2012). The new Pentecostal wave spread well beyond university campuses, eclipsing the 'holiness' churches. In the Prosperity Gospel, disadvantaged groups were promised better lives, as poverty and failure were viewed as the work of evil spirits, and national economic hardships as a manifestation of Satan's influence (Hackett 2012; Marshall 1993; Ojo 2006).

In Nigeria, one of the results of the spread of the Prosperity Gospel among Pentecostal churches is that some of them, especially in urban areas, have become phenomenally wealthy. Therefore, the Pentecostal Prosperity Gospel, which appeared to establish a bridge between religion and wealth, led scholars to return to Max Weber's work, particularly The Protestant Ethic and the Spirit of Capitalism (Weber 1920, original ed. 1904). Whether Pentecostalism establishes a 'Protestant ethic' among its converts has become a substantial key to the current debate concerning its practices (Robbins 2004). Even though these churches provide practices and values for subjectivities to adapt to the neoliberal market economy (Martin 1995; Maxwell 2005), there are significant differences between what Weber described when analyzing sixteenth-century Calvinist Protestants in Europe and Pentecostalism in Africa today. One of the differences between the capitalist ethic described by Weber and the Prosperity Gospel is the latter's emphasis on consumption. According to Weber, Protestant emphasized hard work and reinvestment rather than consumption. However, contemporary neoliberal capitalism is increasingly focused on consumption rather than production, and born-again Christians in Africa expressly desire to accumulate wealth in this life to improve consumerism (Meyer 2007), turning this world into a 'heaven on earth' (Ukah 2011, 198). Consumption is essential to the emergence of a wealthy elite in Africa, one to which born-again Christians aspire and many pastors certainly belong.

When describing the sometimes-extravagant consumption habits of Pentecostal leaders, whether pastors or businesspeople, showing off luxury vehicles and fine clothes in a society still rife with inequalities, the work of Thorstein Veblen seems relevant. Various similarities can be found between Veblen's The Theory of the Leisure Class, written in 1899, and what has occurred in Africa, especially since the 1980s. In Nigeria, as well as in other African nations, wealth has not been transformed into economic justice. In contrast, inequality continues to grow, and some conspicuous and extravagant consumption has attracted strong criticism throughout the continent, generating anxieties that may be broader than those found in the West (Blunt 2019; Dosekun 2017; Mbembe 2006). According to Veblen, accumulating wealth was not enough for the members of the novel upper class; it had to be made visible and public, whether through abstaining from work or by consuming costly objects capable of creating social distance. Flaunting 
decorum, elevated instruction, and proper manners were also viewed as necessary. Even though such practices were either unnecessary or harmful, they were capable of promoting one's status and thus excluding others. As well as producing differences, conspicuous consumption also encourages others to emulate it and improve their social status. Veblen's analyses were not without criticism, both from his contemporaries and later on (for example, Campbell 1995). However, Veblen was one of the first scholars to demonstrate how psychological, political, societal, and economic processes are intertwined with consumption. While looking at Africa, the challenge is to use his work in a suggestive rather than conclusive manner (van Wyk and Posel 2019).

Some aspects of Nigerian Pentecostalism's consumer practices seem to be consistent with Veblen's analyses of conspicuous consumption, despite obvious differences in historical and geographical context. Conspicuous consumption is characterized by goods that serve a positional purpose for the individual, and these goods change over time. For example, in Nigeria, despite its prohibitive price, the latest iPhone model is certainly one of those commodities that many seek to own, instead of just an old cell phone. Today, born-again Christians regard such expensive items as a sign of divine blessing and social distinction, and by avoiding others, such as alcohol, they can further distinguish themselves. However, years earlier, Western missionaries had already brought objects that soon replaced local ones, and their conspicuous consumption allowed converts to distinguish themselves even from previous elites (Meyer 1998). Through prayers and business courses organized by various Nigerian Pentecostal churches, people learn to start their own businesses instead of working as mere employees (Freeman 2012). Several Pentecostal services in Nigeria address topics such as dressing well and cultivating upward manners, and in addition to these practices, being a Pentecostal Christian rather than a nonbeliever is already a measure of social distinction. Many people will wear expensive clothing items only on Sundays but joining one of these churches means hoping to elevate one's status permanently while distancing oneself from others. As a final point, examples such as the 'Gucci Pastor' assist us in understanding the importance Pentecostalism attaches to publicly displaying conspicuous consumption, whose accomplishment functions as an inspiration to many born-again Christians.

Pastor 'Gucci' Fatoyinbo became popular on the internet for a photo in 2017 featuring him wearing a Gucci Hoodie worth $\$ 1,280$. Similar pictures are regularly posted on Nigerian online discussion forums, such as Nairaland.com, where supporters and detractors engage in heated discussions. In the same way as other power figures, the pastor's social success and flamboyant aesthetics seduce and captivate followers while intimidating others as a sublime expression out of the ordinary (Kuldova 2017). The stories concerning the private jets owned by one pastor or another, or the numerous online rankings of the wealthiest pastors in the continent, further demonstrate how consumption attracts and at the same time unsettles born-again Christians in Africa. Over the years, pastors have increasingly captured the public's imagination, emerging as spiritual, political, and financial 
leaders, as well as models to emulate, à la Veblen. A recent article by Ebenezer Obadare examined Pentecostal pastors as charismatic 'porn stars,' whose domestic sexual lives are of increasing public interest (Obadare 2018). As all-around public celebrities, Pentecostal pastors are also becoming charismatic 'consumer stars' and fashion icons. The heavy use of social media has contributed to their popularity as 'the society's most successful persona... the human being closest to God and, in a social sense, to the big man' (Pype 2010, 130). Their flashy clothing, passion for luxury cars, multi-story homes, and sorted hairstyles are evidence that those objects of desire are now within reach for born-again Christians.

Conspicuous consumption, as it emerges from Pentecostal experiences, is part of a more general social and symbolic process through which elites in Africa construct and distinguish themselves today (Daloz 2002). Colonial elites already revealed their dominance through exploitations and libidinal investment in goods found even more desirable when scarce (Mbembe 2006). Postcolonial leaders in Nigeria also indulged in conspicuous consumption, particularly during the 1970s, when the oil producer country imported luxury goods in a rush for wealth that would fade in the 1980s (Apter 2008). The Prosperity Gospel led to the emergence of subjectivities filled with a desire to enjoy such scarce objects again, unaffected by previous debts, kinship obligations, or ascetic religious morals. Pentecostal doctrines and narratives enable Pentecostal elites to legitimize their social position and conspicuous consumption. However, their extravagant lifestyles do not only inspire others but also expose them to criticism, as evidenced when a scrutinizing public accuses them of being 'corrupt' or 'fake.'

\section{The Perils of Consumerism: Pentecostal Pastors and Discourses of Corruption and Fakery}

Haynes (2012) argues that in addition to indicating one's successful economic position, conspicuous consumption among born-again Christians signals the ability to engage, and to invest, in extensive networks of exchange. Many scholars consider these networks, often in the form of patron-client relations, to be central to the politics and economy of Nigeria and elsewhere in Africa (Smith 2001; Bayart 2009; Chabal and Daloz 1999). Therefore, while providing legitimacy for conspicuous consumption, Pentecostal Christian morality also facilitates the involvement of Pentecostal leaders in various worldly activities. For example, Chris Okotie, after a brief music career and as a student at the Grace Fellowship Bible School in Tulsa, Oklahoma, established the Household of God Church International Ministries in Lagos in 1987. In 2011, Forbes estimated his net worth at US\$3-10 million (Nsehe 2011) - a wealth that is evident to his followers by his passion for Porsches, Hummers, and Mercedes. Besides his business activities, Okotie also attempted to become president in 2003 from the ranks of the Justice Party. Despite failing to do so, he founded his own party in 2006, the Fresh Democratic Party. Though individual pastors like Okotie have had limited electoral success, Pentecostalism's institutional influence and role have grown significantly since the restoration of democracy in Nigeria in 1999 (Obadare 
2018b). Olusegun Obasanjo, known for his alliances with Pentecostal leaders, won the 2003 elections due to the significant Pentecostal support he garnered after his presumed conversion. An explanation for such a phenomenon may be due to a conception of Africa's political and religious spheres, which were never strongly demarcated as in the West (Meyer 2004). Indeed, the ontology of political power is often perceived as spiritual (Marshall 2009), and consequently, the world of politics is heavily influenced by such assumptions (Lindhardt 2014), even though classical secular ideologies in the West would see this influence of the sacred on politics as an undesirable one. Still, the ability for some Pentecostal leaders to move between various social sectors extends far beyond the world of politics.

Pentecostal churches in Nigeria are usually registered under the auspices of the Companies and Allied Matters Act of 1990, as revised in 2004, issued by the Corporate Affairs Commission of Nigeria (Ukah 2015). The body is responsible for regulating organizations that meet the requirements for nonprofit status. The proper registration of a church ensures perpetual legal succession and the ability to acquire, hold, assign, dispose, or transfer properties. In addition, nonprofit organizations are tax-exempt under the Company Income Tax Law of 2004. For example, the full name of one of the most famous Pentecostal churches in Nigeria, the Redeemed Christian Church of God (RCGG) is actually The Incorporated Trustees of The Redeemed Christian Church of God. Still, churches such as the RCCG possess incredible financial power, allowing them to engage in activities that seem to defy Nigerian charitable and not-for-profit regulations regarding 'incorporated trusteeships.' Though not directly overseen by the founder of the RGCG, Enoch Adeboye, the church has built up a network of industrial interests, holdings in real estate, private universities, schools, hospitals, and at least four church-related banks. All of them claim to have been founded following the founder's vision. As a result, the RCGG can sponsor and offers products for its members, such as soft loans for proselytizing initiatives (Ukah 2011). Pastors and born-again Christians can navigate these diverse social spaces, and the bonds formed can be strengthened by the shared act of sacrifice with God represented by the tithe, which makes the giver a client with the right to expect rewards, although he may not know precisely when (Coleman 2014; Premawardhana 2012). In the broader society, particularly in the West, such forms of relationships based on shared linguistic, religious, communal, or kinship ties would be accused of undermining criteria of merit and accountability; however, within the church, these forms of patronage networks are justified as moral (Marshall 2009; Smith 2021).

Through national and international connections, the church seems to embody an example of a 'moral economy of corruption,' a dynamic analyzed by many scholars in Africa in which patrons appear corrupt only to third parties, while they are perceived internally as merely providing opportunities to dependents within their networks (Bayart 2009; de Sardan 1999; Smith 2010). Indeed, as anthropology has amply demonstrated, corruption is a highly elusive category. The judgment by the actors involved in corrupt practices is highly processual, 
evaluative, and, in short, is hardly definitive (de Sardan 1999; Pierce 2016; Roitman 2005; Smith 2010). However, the most famous definition of corruption, disseminated primarily by organizations like the IMF and the World Bank following the Cold War, focuses almost exclusively on the appropriation of public resources for personal benefit. Consequently, in numerous African countries, corruption has been identified mainly as a government and bureaucratic problem rather than a private sector issue (Wedel 2012), and anti-corruption efforts, such as 'good governance', often resulted in increased neoliberal policies (Katzarova 2018). Nonetheless, focusing on individual transactions of state officials tends to omit the broader, elitist networks of contemporary corruption. These networks, involving business, politics, and nonprofits domains as well, are not exclusively or peculiarly African. The ease with which Pentecostal leaders in Africa have been able to navigate between public and private sectors while advancing their agendas, as well as to legitimize their elitist consumption, might be indicative of a larger proliferation of brokers participating in the global contemporary economy. As in many Western countries, actors who move through flexible networks, affecting a wide range of sectors within society, with a certain degree of plausible deniability regarding their respective roles, are at the center of exchanges that only rarely become public 'corruption' scandals (Wedel 2012).

Pentecostal leaders in Nigeria are not always required to disclose information about all the enterprises in which they are directly or indirectly involved. Therefore, the full scope of their activities is often challenging to establish, even though their popularity is also associated with their ability to participate in so many upper-class settings. Moreover, many Pentecostal leaders can use their position in the business world as a moral justification for their profits. As Ifechi ${ }^{1}$, a member of the RGGC in Rome with whom I spoke in 2021, asserts: 'many pastors do not require church funds to become wealthy, since they are already rich due to their collateral business activities.' However, since Pentecostal pastors represent an emerging African elite, this process can be somewhat ambiguous, even for born-again Christians. Therefore, both the public and even religious communities are increasingly scrutinizing pastors' activities to learn more about their businesses. 'These pastors enjoy visiting rich men's houses, being buddies to top personalities in the society, worshipping on the altar of waivers and patronage system,' writes Afolorunso Olalekan Dairo, a professor in the Department of Christian Religious Studies at the Redeemed University. 'They do not bother knowing how their so-called elders get the huge offerings and tithes; knowingly or unknowingly, they have entered into an unholy alliance with the political elite to steal the commonwealth and live a life of affluence and showmanship' (Dairo 2020, 244). Thus, these diverse and sometimes inscrutable alliances raise suspicions that some Pentecostal pastors will do anything, in secret, to grow their congregations and their own 'belly' (Bayart 2009). Besides legitimate business, they may also form alliances with forces that do not reflect Pentecostal morality and instead act in the world of darkness (Comaroff and Comaroff 1999; Marshall

1 To protect their privacy, all names of people interviewed are pseudonyms. 
2009). Several news stories illuminate how such hidden entanglements are supposed to work, as in the 1996 Owerri riots. During that period, newspapers reported a ritual murder at a prominent hotel in the Nigerian city, frequented by international travelers and city's elites: the Otokoto Hotel. Journalists published pictures of a decapitated child, whom an employee at the facility allegedly killed. However, the city's residents somehow expected such a horrifying act to happen. Many rumors were circulating in the city about evil rituals conducted to acquire wealth, forcing the rest of the population to pay a spiritual and physical price for the success of a few new riches. In the doctrine of Pentecostal spiritual warfare, evil forces on earth, such as witches and demons, and their human agents may offer to people, including those in business, such fast, but utterly immoral means of gaining wealth. Born-again Christians are those who use their prayers to combat such evil forces (Marshall 2016). However, in the Otoko Hotel case, there were rumors that the remains of a 'human meat pepper soup' had also been discovered at the Pentecostal church that the man attended. Therefore, amidst suspicions, the pastor's hidden alliances popularly emerged into the light, and the angry mob stormed the church, as well as other buildings (Smith 2001).

While many discourses on corruption surrounding Pentecostal pastors seem to scrutinize the illegitimate alliances that may underlie their business success, others examine the offers they may receive from the congregation and how they may be using them. The interpretation of offerings as a way to gain immediate returns may be overly utilitarian (Lauterbach 2019); however, their final destination still gives rise to widespread suspicion among born-again Christians. Offerings, tithes (as a form of thanksgiving for a positive event in one's life), and seeds (made when one wishes to receive a specific blessing) are all forms of monetary donations accepted by Pentecostal churches in Nigeria and abroad. These forms of financial input can become substantial, without accounting for the gifts that pastors may receive from individual donors. In a conversation with RCGG members in Rome in 2021, it became evident that the final purpose of these contributions strongly determined the legitimacy of the pastor's activities. Some church members viewed the offerings as something that they addressed directly to God through the pastor, and it was not up to them to check their final destination. Others, however, believed that auditing by themselves such offerings was essential to carrying their fruits to the religious community. Their interest in the destiny of the offerings mainly stemmed from popular stories about corrupt Pentecostal pastors diverting members' offerings. Indeed, the Nigerian Economic and Financial Crimes Commission's operations against Pentecostal pastors and their churches frequently make headlines in Nigerian newspapers. In 2019, a pastor in Rivers State was arrested for defrauding a family of 25,000,000 naira under the pretense that he was a business contractor. False prophecies were used to justify the collection of the sum (Azubuike 2019). Another pastor from Lagos was arrested in 2018 for defrauding a member of 85,000,000 naira, before trying to avoid arrest. He was also rumored in the city to bury animal heads in the church to increase his personal wealth (Oladele 2018). 
These popular discourses describing the corruption of Pentecostal pastors, which are also found in the media, illustrate how Pentecostal prosperity may be mismanaged, separating it from the well-being of a community (Coleman 2014; Lauterbach 2019). Thus, they are also part of a general discussion about the moral boundaries between legitimate and illegitimate consumption. For many born-again Christians, the Pentecostal Prosperity Gospel encourages consumption by assuring others that they too can achieve such symbolic status. Indeed, observing the Instagram accounts of various pastors in Nigeria who post pictures of their most recent earthly possessions, Amadi, one of the RGGG members in Rome, observed: 'Did Jesus flaunt his miracles? Yes. If not, he could not have allowed the whole world to know the right path. Posting online God's blessings is not a sin.' However, as he also added later on, 'It is not a crime to be rich as a Christian; but what you do with the wealth matters. One should use the wealth to help the poor and the needy and to propagate the gospel of salvation and righteousness.' While born-again status implies a complete break with one's past social network (Meyer 1998b), which allows for more independence over consumption, similar breakdowns in reciprocity are common to other ambiguous practices, such as witchcraft. Therefore, while 'customary' consumption established extended bonds through exchange and reciprocity, Pentecostal consumption has the potential to become perceived as immoral, greedy, and therefore, corrupt. As Martin Lindhardt suggested, when 'Pentecostal/ Charismatic ministry in too obvious ways becomes a business venture and when adherents or consumers fail to see the material fruits of spiritual assistance, doubt can easily be shed' (2014b, 154). If the pastor's consumption has no positive outcomes for society or is entirely selfish, his figure dangerously resembles that of other evil forces, which secretly consume to the detriment of others (Newell 2007). Pastors are allowed to become wealthy and consume conspicuously, but a significant part of their prestige and the legitimacy of their message is determined by the extent to which others will also be able to enjoy the same. Even those members of the RGGC in Rome who did not intend to personally verify the outcomes of their offerings were at least hoping that the church would redistribute them to support charitable efforts or benefit the congregation; in other words, to make such forms of spending 'social.'

There are also types of consumption that can never show God's favor or elevate the status of a born-again individual. There is no likelihood, in fact, of a Pentecostal pastor advocating for sex escorting or cocaine abuse as legitimate and distinctive forms of consumption, no matter how costly they are. Instead, these are clear signs of fakery to almost everybody in Nigeria. Additionally, when the objects acquired by born-again Christians are obtained through illicit, deviant, and occult means, they cease to be a sign of divine blessing or a source of inspiration, ultimately becoming spiritually hazardous. As a result, prayers are performed in the church in the case of doubts to guarantee the legitimacy of previous donations or acquisitions and cleanse them of any ambiguities that might arise otherwise (Meyer 1998; Lindhardt 2015). Likewise, it is also evident that, following prayer, practices that would otherwise appear corrupt to external 
observers eventually become morally acceptable; this is also true for consuming virtually any object, including those produced by companies that can hardly be characterized as Christian. For example, Procter \& Gamble, Nestlé Foods, Coca Cola, along with banks, insurance companies, and telephone companies, have been able to present themselves as 'ethical' corporations through donations to the RCGG, and in return, have received more sales in the marketplace by becoming sponsors of the church. The Nigerian Brewery Plc. donated 20 billion naira to a Lagos parish for a special annual program to sell its soft drinks exclusively. The London-based Cloud 7 Cruises organized a weeklong cruise, under the title Heaven on the Seas Conference, from Miami to the Bahamas in 2004 (Ukah 2011). By moving beyond the relationship between the born-again individuals and God through some ambiguous commercial enterprise, these operations may raise widespread suspicion of consumption and, therefore, even accusations of corruption, at least from the not born-again public.

Eventually, in addition to the ambiguous origin and purpose of consumptions and the revelation of shady alliances, many of the corruption scandals involving Pentecostal pastors also raise an important question about what people are willing to do to become exceptional businesspeople, as advised in many Pentecostal services. Although the Prosperity Gospel aligns born-again Christians to the wealthy class, in the adverse economic and structural environment of Nigeria today, money scams and ambiguous pyramid schemes are often the only 'business' left and therefore are also offered by Pentecostal congregations in Africa (Quiroz 2016). In 2016, while conducting research in Port Harcourt (Casciano 2021), I witnessed one of these schemes, the MMM, unfold on the premises of a Pentecostal church. Sergei Mavrodi originally established MMM in Russia as a multi-marketing pyramid scheme, also known as a Ponzi scheme. In essence, previous investors remunerated each newcomer with the capital recovered from other new subscribers. Thus, there was only a shift of money from new investors with which to repay the old investors, until the first investor disappeared with most of the capital. Sergei was arrested, and eventually released in 2007. However, the scheme was revived in 2015 in Indonesia, South Africa, and Nigeria, where Sergei's story was unknown. In 2017, the RCCG warned its adherents not to take part in MMM precisely because of some scandals involving the role played by a number of pastors in recommending this scheme to their congregations (Opejobi 2017). Nevertheless, no one had previously provided information about MMM to the congregation I was visiting that afternoon in 2016. In light of this, after the service, I felt compelled to read to the congregants what an internet search brought to my attention about MMM. However, due to their attitude toward investing, to being 'owner of their own business,' and to their inspiring, successful, and consumerist model, they were willing to accept the outcomes of this ambiguous scheme similar to other ones that had occurred to them in the past. Their point was that, in an environment of such substantial inequalities as Nigeria today, it is essential to be blessed by God while conducting business and to observe Christian morals; but without taking risks, even considerable ones, no one will achieve anything. As some scholars have argued, if neoliberal reforms spread 
norms and values, such as competition, to create subjectivities able to dominate the social and economic scene, then fraud may be one of its features, more than a deviation, a part of its moral culture: a 'moral economy of fraud' (Whyte and Wiegratz 2016).

\section{Conclusion}

During the 1980s, the widespread dissemination of the Prosperity Gospel in Nigeria ignited the Pentecostal movement, legitimizing material well-being, which had previously been denied by the Pentecostal 'holiness' movement. Against the backdrop of the development of neoliberal policies, the Prosperity Gospel enabled the emergence of subjectivities able to adapt to the characteristics of the new markets. Additionally, it also symbolically offered the opportunity to the larger population to join a new elite class characterized by solid access to conspicuous consumption. Therefore, Pentecostal pastors have become all-around celebrities in Nigerian society, inspiring the population and their consumption desires. While few consumer items and habits have been prohibited, many ambiguous others have gained a new moral legitimacy. These emerging Pentecostal elites demonstrate how becoming a born-again Christian is an opportunity to acquire social status, stand out, and consume otherwise scarce and expensive items. Furthermore, the public is intrigued by their ability to interact within restricted and elevated social networks, occupying multiple roles in official and unofficial capacities within public and private sectors. The relevance and success of Pentecostalism on the one hand reflect the benefits of joining these networks, and on the other hand, the moral legitimacy that the Prosperity Gospel provides to its peculiar social configuration.

At the same time, pastors' conspicuous consumption and their exceptional aesthetics and social status inevitably attract suspicion. Several allegations of fraud and corruption have been raised from different sectors of society, becoming part of the social discourse on corruption in Nigeria. Pentecostal pastors' involvement in public politics and other social networks generates widespread concerns that some of these circles may have been kept secret, even from their congregation members. Therefore, from the outside and within the religious community, concern seems growing regarding the legitimacy of the consumption of this new elite and its accountability. The Prosperity Gospel provides Pentecostal leaders with evidence that they can live comfortably in this life, which became a legitimate necessity to communicate their religious message effectively and coherently. However, at the same time, their consumption is only exempt from criticism of corruption so long as other church members eventually enjoy the same benefits. As such, these discourses of corruption seem to indicate the perception of the existence of behaviors that have been labeled corrupt based on their explicitly destructive, antisocial, immoral nature. Such accusations appear to indicate an intention to control the actions of a few false pastors, whose deviance resembles that of other rapacious elites or hidden groups. As individuals deemed capable of behaviors contrary to social and Pentecostal norms, these individuals are accused 
of harming the community in pursuit of a self-attributed 'special liberty' (Hall 2012), which allows them to satisfy their greedy desires at all costs without any collective accountability. Popular accusations of corruption often follow media reports of frauds perpetrated by pastors against members of their same congregations. The wider the gap between pastors and the general population becomes, the more the accusations appear to mount. Yet, in a situation of challenging economic possibilities and an apparent lack of viable alternatives, as in Nigeria today, fraud is among the options for survival within a capitalist neoliberal market, which subjectivities seek to exploit.

In conclusion, by showing how conspicuous consumption may lead to greedy desires for revenues, fraud, and luxurious pleasures, these popular accusations illustrate the perceived risks associated with it and its entanglement with allegations of corruption. These popular tales of corruption, as with other grassroots accountability processes undertaken in Africa (Adebanwi and Orock 2021), seem to play an instrumental role in determining the morality of the actions performed by the Pentecostal elites amid the ambiguous space of maneuver that the Prosperity Gospel offers. In addition to the accusation directed at 'fake' pastors by external commentators, born-again Christians are increasingly scrutinizing the practices of this emerging elite, observing the roots and destinations of their consumptions, how they are made collectively acceptable, and how some of them are motivated by a deviant lack of morals. Yet, the alleged 'corrupt' pastors are not those who simply consume conspicuously within their multiple networks, but those who fail to distribute their benefits to the broader religious community, transforming their sumptuous wealth, even that gained through God's blessing, into an example of 'public virtue.' What often eludes public policy does not seem to escape public imagination, revealing corruption as a much more complex phenomenon than the misuse of public resources for personal gain, one that goes hand in hand with the growing inequalities of our time.

\section{Author Bio}

Davide Casciano obtained his Ph.D. in Social Anthropology from Sapienza University in 2018. After spending a period as a Visiting Researcher at the University of the Witwatersrand in Johannesburg, South Africa, he joined the University of Bologna in Italy in 2021 as a Researcher within the LUXCORE project and as an Adjunct Professor of Social Anthropology. His research interests include African religions, politics, conflicts, crime, corruption, and Information \& Communication Technologies (ICTs). Most of his fieldwork has been conducted in Nigeria and South Africa. He is currently chair of the European Association of Social Anthropologists' network on the Anthropology of Crime and Criminalization (AnthroCrime). 
Davide Casciano - Popular Tales of Pastors, Luxury, Frauds and Corruption

\section{Funding}

This study was funded by the Research Council of Norway, through the project LUXCORE: Luxury, Corruption and Global Ethics, project number 313004.

\section{Acknowledgments}

The author would like to thank his colleagues within the LUXCORE project, including the members of the advisory board, for a preliminary discussion of this article, as well as the editors of this journal issue, Tereza Østbø Kuldova, Thomas Raymen, and Jardar Nuland Østbø, for comments and suggestions on this article.

\section{References}

Adebanwi, Wale, and Rogers Orock. 2021. Elites and the politics of accountability in Africa. Ann Arbor: University of Michigan Press.

Anderson, Allan. 2013. An introduction to Pentecostalism: global charismatic Christianity. Cambridge: Cambridge University Press.

Apter, Andrew. 2008. The Pan-African Nation: Oil and the Spectacle of Culture in Nigeria. Chicago: University of Chicago Press.

Azubuike, Victor. 2019. "N25million Scam: EFCG arrests fraudulent pastor in Port Harcourt." Daily Post, July 29, 2019. https://dailypost.ng/ 2019/07/29/n25million-scam-efcc-arrests-fraudulent-pastor-portharcourt/

Bayart, Jean-Francois. 2009. The State in Africa: The Politics of the Belly. Paris: Wiley.

Blunt, Robert W. 2019. “5. "Satan Is an Imitator”: Kenya's Recent Cosmology of Corruption." In: Robert W. Blunt, For Money and Elders: Ritual, Sovereignty, and the Sacred in Kenya, 118-143. Chicago: University of Chicago Press. https://doi.org/10.7208/9780226655895-005

Campbell, Colin. 1995. “Conspicuous Confusion? A Critique of Veblen's Theory of Conspicuous Consumption." Sociological Theory 13(1): 37-47. https:// doi.org/10.2307/202004

Cartledge, Mark J. 2008. "Pentecostal Theological Method and Intercultural Theology." Transformation: An International Fournal of Holistic Mission Studies 25(2-3): 92-102. https://doi.org/10.1177/026537880802500304

Casciano, Davide. 2021. "Between God and the state: Pentecostalism and articulated sovereignty in the Niger Delta, Nigeria." Canadian Fournal of African Studies / Revenue canadienne des études africaines. https://doi.org/ $\underline{10.1080 / 00083968.2021 .1988666}$ 
Davide Casciano - Popular Tales of Pastors, Luxury, Frauds and Corruption

Chabal, Patrick, and Jean-Pascal Daloz. 1999. Africa Works: Disorder as Political Instrument. London: James Currey.

Coleman, Simon. 2014. "Between Faith and Fraudolence? Sincerity and Sacrifice in Prosperity Christianity." In: Amanda van Eck Duymaer van Twist, eds., Minority Religions and Fraud. In Good Faith, London: Ashgate Publishing, pp. 73-89.

Comaroff, Jean, and John L. Comaroff. 1999. "Occult economies and the violence of abstraction: notes from the South African postcolony." American ethnologist 26.2: 279-303. https://doi.org/10.1525/ae.1999.26.2.279

Dairo, Afolorunso Olalekan. 2020. "Sacred corruption in sacred places: the case of some selected Neo Pentecostal Churches in Nigeria." Arts \& Humanities Open Access Journal 4(6): 241-244.

Daloz, Jean-Pascal. 2002. Élites et représentations politiques: la culture de l'échange inégal au Nigeria. Pessac: Presses Universitaries de Bordeaux.

de Sardan, J. P. Olivier. 1999. "A moral economy of corruption in Africa?" Fournal of Modern African Studies 37(1): 25-52.

Dosekun, Simidele. 2017 "The Risky Business of Postfeminist Beauty." In: Elias A., Gill R., Scharff C., eds., Aesthetic Labour. Dynamics of Virtual Work. London: Palgrave Macmillan. https://doi.org/ $\underline{10.1057 / 978-1-137-47765-1 \quad 9}$

Freeman, Dena. 2012. Pentecostalism and Development. Churches, NGOs and Social Change in Africa. London: Palgrave Macmillan.

Hackett, Rosalind I. J. 2012. "The gospel of prosperity in West Africa." In: Roberts, Richard H., eds. Religion and the Transformation of Capitalism. New York: Routledge, pp. 211-226.

Hall, Steve. 2012. Theorizing crime and deviance: A new perspective. London: Sage.

Haynes, Naomi. 2012. "Pentecostalism and the morality of money: prosperity, inequality, and religious sociality on the Zambian Copperbelt." Fournal of the Royal Anthropological Institute 18: 123-139. https://doi.org/10.1111/ j.1467-9655.2011.01734.x

Katzarova, Elitza. 2018. The Social Construction of Global Corruption: From Utopia to Neoliberalism. Cham: Palgrave Macmillan.

Kuldova, Tereza. 2017. "The Sublime Splendor of Intimidation: Outlaw Biker Aesthetics of Power", Visual Antropology 30(5): 379-402. http://dx.doi.org/ $\underline{10.1080 / 08949468.2017 .1371545}$ 
Lauterbach, Karen. 2019. "Chapter 6 Fakery and Wealth in African Charismatic Christianity: Moving beyond the Prosperity Gospel as Script." In: Lauterbach, Karen, and Mika Vähäkangas, eds. Faith in African Lived Christianity. Leiden: Brill, pp. 111-132. https://doi.org/ $\underline{10.1163 / 9789004412255007}$

Lindhardt, Martin. 2014. Pentecostalism in Africa: presence and impact of pneumatic Christianity in postcolonial societies. Leiden: Brill.

Lindhardt, Martin. 2014b. "Miracle Makers and Money Takers: Healers, Prosperity Preachers and Fraud in Contemporary Tanzania." In: Amanda van Eck Duymaer van Twist, eds., Minority Religions and Fraud. In Good Faith, London: Ashgate Publishing, pp. 153-170.

Lindhardt, Martin. 2015. "Are blessings for sale? Ritual exchange, witchcraft allegations, and the de-alienation of money in Tanzanian prosperity ministries." In: Hauser, Andres, eds., Pastures of Plenty: Tracing Religio-Scapes of Prosperity Gospel in Africa and Beyond. Frankfurt: Peter Lang, pp. 309-23.

Lipovetsky, Gilles. 1987. L'empire de l'éphémère: la mode et son destin dans les sociétés modernes. Paris: Gallimard.

Marshall, Ruth. 1993. "Pentecostalism in Southern Nigeria: an Overview." In: Gifford, Paul, eds. New dimensions in African Christianity. Ibadan: Sefer Boks Ltd, pp. 8-39.

Marshall, Ruth. 2009. Political spiritualities: The Pentecostal Revolution in Nigeria. Chicago: University of Chicago Press.

Marshall, Ruth. 2016. "Destroying arguments and captivating thoughts: Spiritual warfare prayer as global praxis." Fournal of Religious and Political Practice 2(1): 92-113. https://doi.org/10.1080/20566093.2016.1085243

Martin, Bernice. 1995. "New Mutations of the Protestant Ethic among Latin American Pentecostals." Religion 25(2): 101-17.

Maxwell, David. 2005. "The Durawall of faith: Pentecostal spirituality in neoliberal Zimbabwe." Journal of religion in Africa 35(1): 4-32.

Mbembe, Achille. 2006. "La colonie: son petit secret et sa part maudite." Politique africaine, 102(2): 101-127. https://doi.org/10.3917/polaf.102.0101

Meyer, Birgit. 1998. "Commodities and the power of prayer: Pentecostalist attitudes towards consumption in contemporary Ghana." Development and change 29(4): 751-776. https://doi.org/10.1111/1467-7660.00098 
Davide Casciano - Popular Tales of Pastors, Luxury, Frauds and Corruption

Meyer, Birgit. 1998b. "Make a Complete Break with the past." Memory and PostColonial Modernity in Ghanaian Pentecostalist Discourse." Fournal of Religion in Africa 28(3): 316-349. https://doi.org/10.2307/1581573

Meyer, Birgit. 2004. "Christianity in Africa: From African Independent to Pentecostal-Charismatic Churches." Annual Review of Anthropology 33: 447-474. https://doi.org/10.1146/annurev.anthro.33.070203.143835

Meyer, Birgit. 2007. "Pentecostalism and neo-liberal capitalism: Faith, prosperity and vision in African Pentecostal-Charismatic churches." Fournal for the Study of Religion 20(2): 5-28.

Mohr, Adam. 2013. "Faith Tabernacle congregation and the emergence of Pentecostalism in colonial Nigeria, 1910s-1941." Fournal of religion in Africa 43(2): 196-221. https://doi.org/10.1163/15700666-12341249

Newell, Sasha. 2007. "Pentecostal Witchcraft: Neoliberal Possession and Demonic Discourse in Ivoirian Pentecostal Churches." Journal of religion in Africa 37(4): 461-490. https://doi.org/10.1163/157006607X230517

Nsehe, Mfonobong. 2011. "The Five Richest Pastors in Nigeria." Forbes, June 7, 2011. https://www.forbes.com/sites/mfonobongnsehe/2011/06/07/thefive-richest-pastors-in-nigeria/

Obadare, Ebenezer. 2018. "The Charismatic porn-star: social citizenship and the West-African Pentecostal erotic." Citizenship Studies 22(6): 603-617.

Obadare, Ebenezer. 2018b. Pentecostal republic: Religion and the struggle for state power in Nigeria. London: Zed Books.

Ojo, Matthews A. 2006. The end-time army: Charismatic movements in modern Nigeria. Asmara: Africa World Press.

Oladele, David. 2018. "EFFC, police storm Lagos church, arrest pastor over scam." Legit, November 05, 2018. https://www.legit.ng/1202014-efccpolice-storm-lagos-church-arrest-pastor-scam.html

Opejobi, Seun, 2017. "MMM: Redeemed church warns pastors, members against participating in Ponzi scheme», Daily Post, January 24, 2017. https:// dailypost.ng/2017/01/24/mmm-redeemed-church-warns-pastorsmembers-participating-ponzi-scheme/

Pierce, Stephen. 2016. Moral economies of corruption: state formation and political culture in Nigeria. Durham, NG: Duke University Press.

Premawardhana, Devaka. 2012. 'Transformational tithing: sacrifice and reciprocity in a Neo-Pentecostal church', Nova Religio: The fournal of 
Davide Casciano - Popular Tales of Pastors, Luxury, Frauds and Corruption

Alternative and Emergent Religions 15, 4: 85-109. https://doi.org/10.1525/ $\underline{\text { nr.2012.15.4.85 }}$

Pype, Katrien. 2010. "Of fools and false pastors: tricksters in Kinshasa's television fiction." Visual Anthropology 23(2): 115-135. https://doi.org/ $\underline{10.1080 / 08949460903472960}$

Quiroz, Sitna. 2016. "Seeking God's blessings: Pentecostal religious discourses, pyramidal schemes and money scams in the southeast of Benin Republic." In: Whyte, David and Jörg Wiegratz, eds., Neoliberalism and the Moral Economy of Fraud, New York: Routledge.

Robbins, Joel. 2004. "The Globalization of Pentecostal and Charismatic Christianity." Annual Review of Anthropology 33: 117-143.

Roitman, Janet. 2005. Fiscal disobedience: an anthropology of economic regulation in central Africa. Princeton, NJ: Princeton University Press.

Smith, Daniel Jordan. 2001. "The Arrow of God': Pentecostalism, Inequality, and the Supernatural in South-Eastern Nigeria." Africa 71(4): 587-613. http:// dx.doi.org/10.3366/afr.2001.71.4.587

Smith, Daniel Jordan. 2010. A culture of corruption: Everyday Deception and Popular Discontent in Nigeria. Oxfordshire: Princeton University Press.

Smith, Daniel Jordan. 2021. "The Pentecostal prosperity gospel in Nigeria: paradoxes of corruption and inequality." The Fournal of Modern African Studies 59(1): 103-122. https://doi.org/10.1017/S0022278X2000066X

Torsello, Davide. 2021. "The ethnographic study of corruption.” In: Bågenholm, Andreas et al., eds. The Oxford Handbook of the Quality of Government, pp. 162-177.

Ukah, Asonzeh. 2011. "God Unlimited: Economic Transformations of Contemporary Nigerian Pentecostalism.” In: Obadia, Lionel and Donald C. Wood, eds. The economics of religion: anthropological approaches. Bingley: Emerald, pp. 187-216. https://doi.org/10.1108/ $\underline{\mathrm{S} 0190-1281(2011) 0000031011}$

Ukah, Asonzeh. 2015. "Obeying Caesar to obey God: the dilemmas of registering of religious organisation in Nigeria." In: Coertzen, Pieter, M. Christian Green, and Len Hansen, eds., Law and Religion in Africa: The quest for the common good in pluralistic societies. Stellenbosch: SUN Press, pp. 309-329.

van Wyk, Ilana, and Deborah Posel. 2019. Conspicuous consumption in Africa. Johannesburg: Wits University Press. 
Davide Casciano - Popular Tales of Pastors, Luxury, Frauds and Corruption

Veblen, Thorstein. 1899. The Theory of the Leisure Class. New York: Macmillian.

Weber, Max. 1920. The Protestant Ethic and the Spirit of Capitalism. New York: Charles Scribner's Sons.

Wedel, Janine R. 2012. "Rethinking corruption in an age of ambiguity." Annual Review of Law and Social Science 8: 453-498. https://doi.org/10.1146/ annurev.lawsocsci.093008.131558

Whyte, David and Jörg Wiegratz. 2016. Neoliberalism and the Moral Economy of Fraud. New York: Routledge. 